БУГРОВ Роман Владимирович - кандидат политическихнаук, доцент кафедрымировойдипломатии и международного права Нижегородского государственного университета им. Н.И. Лобачевского (603950, Россия, г. Нижний Новгород, ул. Ульянова, 2; bougrov@таil.ru)

КУЗОВЕНКОВА Ксения Евгеньевна - студентка Нижегородского института управления - филиала Российской академии народного хозяйства и государственной службы при Президенте РФ (603950, Россия, г. Нижний Новгород, nр-кт Гагарина, 46; ksyuha-rybka23@таil.ru)

НГОМА ЛУХУОЛО Голди мл. - аспирант кафедры зарубежного регионоведения и локальной истории Нижегородского государственного университета им. Н.И. Лобачевского (603950, Россия, г. Нижний Новгород, ул. Ульянова, 2; juniordegoldy1@yahoo.fr)

\title{
НАЧАЛО ПРОЦЕССА ДЕМОКРАТИЗАЦИИ В ТРОПИЧЕСКОЙ АФРИКЕ (НА ПРИМЕРЕ НАРОДНОЙ РЕСПУБЛИКИ КОНГО)
}

\begin{abstract}
Аннотация. В статье рассматривается проблема начала процесса демократизации в Африке. Авторы выявляют причины перехода от однопартийности и плановой экономики к многопартийности и рыночной экономике смешанного типа и делают вывод о вторичности влияния горбачевской перестройки на эти процессы по сравнению с внутренними, по большей части экономическими, факторами.
\end{abstract}

Ключевые слова: Народная Республика Конго, демократизация, факторы, перестройка, либерализация экономики.

$\Pi$ роцесс демократизации во многих африканских странах начался еще в 1980-е гг. Касается это и Республики Конго (Браззавиль). Важно отметить, что ситуация в конголезской экономике в 1980-х гг. была весьма напряженной, даже несмотря на улучшение отношений с Францией (в первую очередь речь идет об экономической составляющей [Ossebi], хотя и не только о ней, конечно; об этом говорил, в частности, будущий глава Пятой республики Ж. Ширак в ходе своего визита в 1980 г. [Clark 2002]). Так, например, в 1984 г. резко вырос дефицит государственного бюджета, что было связано главным образом с ростом расходов на субсидирование предприятий государственного сектора. Общие потери в экономике за период 1980-1984 гг. составили 73 млрд франков КФА, из них только в 1984 г. - 28,5 млрд [Лоемба 1987: 16]. Трудности в экономике продолжились, о чем, например, применительно к 1990 и 1991 гг. писал Б.М. Кивали. Он, в частности, отмечал непропорционально большую роль доходов от нефти (до $70 \%$ поступлений в бюджет) и недостаток доверия со стороны иностранных инвесторов [Кивали 1991: 47-48].

Согласимся также с мнением, согласно которому начиная с 1985 г. в Народной Республике Конго (НРК) - именно так именовалось тогда государство - началось разочарование в проводимой политике в связи со слабыми экономическими показателями. Как следствие, падала популярность и концепции научного социализма. Падение Берлинской стены в конечном итоге ускорило демонтаж политической системы, и начиная с 1990 г., в стране начался переход к многопартийности [Kibaya 2007]. В полной мере этому содействовал и перестроечный процесс в СССР, приведший среди прочего и к резкому уменьшению экономических вливаний в экономику африканских государств.

В этих условиях глава государства Д. Сассу-Нгессо вынужден был начать реформы. В своей автобиографической книге «Манговое дерево, река и мышь» он упоминал о том, как начался процесс политических перемен в стране. В пер- 
вую очередь он отмечал воздействие перестроечного процесса в СССР на его взгляды [Этитиэ 2004: 48]. В итоге уже в 1986 г. было заключено соглашение с МВФ и МБРР. Оно предусматривало предоставление займов и реализацию в стране политики «либерализации экономики». Декларировались сокращение государственного сектора, отказ от централизованного управления хозяйством страны, а также приватизация в ряде секторов экономики. Означенные реформы шли вразрез с официальной линией правящей партии (Конголезской партии труда), в связи с чем ее руководство было вынуждено обосновать новые веяния. Глава партии и государства Дени Сассу-Нгессо, объясняя свою политику, заявлял следующее: «Быть марксистской партией вовсе не означает быть догматической. Наша партия решительно выступила против уклонизма» [Этитиэ 2004: 46-47].

Весьма значимыми были также результаты пленума ЦК КПТ, проходившего на рубеже июня и июля 1990 г. С одной стороны, на этом форуме декларировалась необходимость и дальше следовать социалистическим ценностям, но, с другой стороны, говорилось и о частичном отказе от догм марксизма-ленинизма. Было признано необходимым пересмотреть программные и уставные документы КПТ, разделить функции партии и государства, отказаться от пункта в Конституции о главенствующей роли КПТ.

Укажем также, что важным фактором, оказавшим огромное влияние на африканские государства и приведшим к политическим изменениям, стало требование международных организаций - МВФ и Всемирного банка (ВБ) - о необходимости преобразования органов государственной власти, ликвидации однопартийной системы, внедрения демократических принципов построения государства. Важно также подчеркнуть, что требования в области экономики рассматривались в качестве необходимого условия общей демократизации режимов, которая привела бы к отказу от авторитарного режима. В свою очередь, внедрение демократических норм и процедур должно было представлять собой системообразующий фактор для развития новых экономических отношений [Пахомова 2013: 226].

В целом следует согласиться с мнением, согласно которому программа «политического обновления» была подготовлена прежде всего диаспорой африканских технократов высокого уровня. В состав этой группы входили африканские интеллектуалы. По большей части это были выходцы из университетской среды, финансисты африканской сети Всемирного банка, крупные функционеры (прежде всего, Андре Милонго из НРК и Нисефор Согно из Бенина). Именно благодаря этой африканской интеллигенции концепция «разумного правления» стала началом процесса «политической либерализации» в Африке [Мирзеханов 2001: 108].

Таким образом, следует признать, что основной причиной начала политики демократизации в Народной Республике Конго стал внутренний фактор, связанный с тяжелым экономическим положением, а не внешний в виде столь значимого события, как перестроечный процесс в СССР [Устинкин, Тимофеев 2012: 172].

\section{Список литературы}

Кивали Б.М. 1991. Экономическое сотрудничество Конго и СССР: 80 - начало 90-х годов: дис. ... К.э.н: М. 175 с.

Лоемба А.Ш. 1987. Проблемы социально-экономического развития Народной республики Конго в условиях социалистической ориентации: автореф. дис. ... К.э.н. M. 23 c.

Мирзеханов В.С. 2001. Интеллектуалы, власть и общество в черной Африке (на 
материалах франкоязычных стран региона в последней трети ХХ в.): дис. ... Д.и.н. Саратов. 385 с.

Пахомова Е.А. 2013. К вопросу о многообразии либерализма в современном мире. - Вестник Волжской государственной академии водного транспорта. № 36. С. 225-227.

Устинкин С.В., Тимофеев Г.А. 2012. Раскол социума и нарастание социальной и межэтнической напряженности в СССР в конце 1980-х - начале 1990-х гг. Власть. № 6. С. 170-175.

Этитиэ Ж. 2004. Кризис однопартийного режима и становление многопартийной системы в Республике Конго: дис. ... к.полит.н. М. 152 с.

Clark J.F. 2002. The Neo-Colonial Context of the Democratic Experiment of Congo-Brazzaville. - African Affairs. Vol. 101. P. 171-192.

Kibaya M. 2007. La question du tribalisme et/ou de l'ethnie doit-elle être au centre des questions politiques en Afrique? URL: http://lepangolin.afrikblog.com/ archives/2007/07/12/5599210.html (accessed 30.06.2017).

Ossebi R. France/Congo-Brazzaville. La France trahie par la Françafrique et SassouNguesso. URL: https://blogs.mediapart.fr/jecmaus/blog/090616/francecongobrazzaville-la-france-trahie-par-la-francafrique-et-sassou-nguesso (accessed 30.06.2017).

BUGROV Roman Viktorovich, Cand.Sci.(Pol.Sci.), Associate Professor of the Chair of World Diplomacy and International Law, Lobachevsky State University of Nizhny Novgorod (2 Ul'yanova St, Nizhny Novgorod, Russia, 603950; bougrov@ mail.ru)

KUZOVENKOVA Kseniya Evgen'evna, student of Nizhny Novgorod Institute of Management - the branch of Russian Presidential Academy of National Economy and Public Administration (46 Gagarina Ave, Nizhny Novgorod, Russia, 603950; ksyuha-rybka23@mail.ru)

NGOMA LUKHUOLO Goldi Junior, postgraduate student at the Chair of Foreign Regional Studies and Local History, Lobachevsky State University of Nizhny Novgorod (2 Ul'yanova St, Nizhny Novgorod, Russia, 603950; juniordegoldy1@ yahoo.fr)

\section{THE BEGINNING OF THE DEMOCRATIZATION PROCESS IN SUB-SAHARAN AFRICA (ON THE EXAMPLE OF THE PEOPLE'S REPUBLIC OF THE CONGO)}

Abstract. The article deals with the problem of the beginning of the process of democratization in Africa. The reasons for the transition from single-party and planned economy to multi-party and market economy of mixed type are revealed. The authors make a conclusion about the secondary influence of Gorbachevss perestroika on these processes in comparison with internal, for the most part, economic factors.

Keywords: People's Republic of the Congo, democratization, factors, restructuring, economic liberalization 